\title{
Live-in migrant care worker arrangements in Germany and the Netherlands: motivations and justifications in family decision-making
}

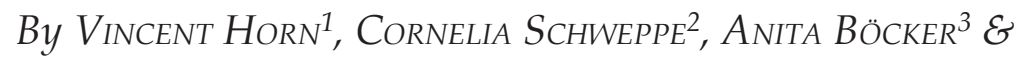 \\ MarÍA BRUQuetas-CALLEJO ${ }^{4}$
}

\begin{abstract}
Private households in ageing societies increasingly employ live-in migrant carers (LIMCs) to care for relatives in need of 24/7 care and supervision. Whilst LIMC arrangements are a common practice in Germany, they are only recently emerging in the Netherlands. Taking this development as a starting point, this study uses the countries' different long-term care (LTC) regimes as the analytical framework to explore and compare the motivations and justifications of German and Dutch family carers who opt for an LIMC arrangment. Findings show that Dutch and German LTC regimes impact differently the decision-making processes of families, as well as on patterns of justification, through a combination of policies and social norms and their related expectations towards care and care work in old age.

\footnotetext{
${ }^{1}$ Vincent Horn, Institute of Education, Johannes Gutenberg University Mainz, Mainz, Germany ${ }^{2}$ Cornelia Schweppe, Institute of Education, Johannes Gutenberg University Mainz, Mainz, Germany

${ }^{3}$ Anita Böcker, Department of Sociology of Law and Centre for Migration Law of the Law Faculty, Radboud University, Nijmegen, The Netherlands

${ }^{4}$ Maria Bruquetas-Callejo, Department of Sociology of Law and Centre for Migration Law of
} the Law Faculty, Radboud University, Nijmegen, The Netherlands
\end{abstract}


International Journal of Ageing and Later Life

Keywords: families, Germany, live-in migrant carers, long-term care, older people, The Netherlands.

\section{Introduction}

The provision of adequate and fiscally sustainable long-term care (LTC) for older people poses a major challenge to ageing societes (OECD 2017). Not only are governments faced with a rapidly growing proportion of older people in need of LTC, but changing family structures and increasing female employment in several European countries simultaneously diminish the pool of informal care providers (Cangiano 2014; Colombo et al. 2011). This development has led to an increasing demand for live-in migrant carers (LIMCs) in private households, although their prevalence varies considerably across European countries (Di Santo \& Ceruzzi 2010; Van Hooren 2012). Whilst LIMC arrangements have become a widespread practice in southern European countries and to a lesser extent in Austria and Germany, they are practically absent in Nordic countries and are just emerging in the Netherlands (Da Roit \& Van Bochove 2017; Da Roit \& Weicht 2013).

Theoretically, cross-country differences in the prevalence of LIMCs have been explained by variations in national LTC regimes (Bettio et al. 2006; Da Roit \& Weicht 2013; Van Hooren 2012). Because Germany and the Netherlands represent very different LTC regimes and traditions (Bettio \& Verashchagina 2012), they are interesting cases to compare. The Netherlands introduced an LTC insurance as early as 1968, providing a broad range of largely publicly funded health and social care services (Maarse $\&$ Jeurissen 2016). By contrast, Germany's LTC insurance, which went into effect nearly 30 years later in 1995, still leaves most of the responsibility to the families (Wetzstein et al. 2015). The strong reliance on the family largely explains why the demand for LIMC arrangements in Germany is higher than that in the Netherlands (Böcker et al. 2017). However, recent studies have indicated an emerging, although still small-scale, market for LIMCs in the Netherlands as well (Da Roit \& Van Bochove 2017). This development occurs in a time of significant policy changes in the Netherlands, which intend to foster deinstitutionalisation and deprofessionalisation in its LTC regime. 
Thus far, comparative studies of LTC regimes and migrant care workers have clustered countries according to specific combinations of care, migration and employment policies, but have paid limited attention to the role of families in this process. However, the concept of a regime not only refers to a set of policies and their interections but also explicitly points to the relation between policy and culture and how this relation influences care preference and everyday care practices and experiences at the micro-level (Bettio \& Plantenga 2004; Williams 2012). According to this approach, care preferences and choices are informed by mutually influencing policies and social norms about caregiving, family and gender relationships (Anderson 2012). Social norms about caregiving engender expectations about family obligatiorns as well as appropriate care arrangements and practices. At the same time, these social norms are more than just rules which simply get applied: "Their importance enters the scene through a sense (...) that there is an external audience who observes what goes on and make judgments about it" (Finch \& Mason 1993: 27). Moreover, social norms about caregiving are no fixed entities; they can be challenged through policy change and social actors such as organisations, families, etc. (Pfau-Effinger 2005).

This article takes up this understanding of regime as a sensitising concept to analyse and compare the motivations and justifications of family decision-making in hiring an LIMC in Germany and the Netherlands. Concretely, the article addresses the following research questions: What motivates German and Dutch families to employ an LIMC and how do they justify their decision? How do their motivations and justifications relate to institutional, cultural and political factors in both countries? In the first section of this article, the scope and features of LIMC arrangements in Germany and the Netherlands are described using both secondary literature and insights gained from stakeholder interviews. ${ }^{1}$ In the second section, the different prevalence of LIMC arrangements in the two countries is explained by comparing the different LTC regimes. In the third section, findings from semistructured interviews with 24 German and

\footnotetext{
${ }^{1}$ Besides semi-structured interviews with 24 primary family carers, stakeholder interviews were conducted as part of a mapping study, 28 in the Netherlands and 14 in Germany.
} 
International Journal of Ageing and Later Life

Dutch primary family carers are presented and discussed in light of the different LTC regimes and recent reforms in LTC in both countries.

\section{Scope and Features of LIMC Arrangements}

Demographically speaking, Germany and the Netherlands experience the ageing of their societies at a similar pace. In both countries, the population of over 80 year olds - the group with the highest risk for needing LTC - has grown by almost one-third during the last decade (OECD 2017). With $5.6 \%$, the share of this population group is slightly larger in Germany than in the Netherlands (4.3\%), as is the number of people with dementia per 1000 inhabitants (20.2 vs. 16.1, OECD 2017). The growing demand for LTC has led to the widespread use of LIMCs in Germany, whereas in the Netherlands, this development has not taken place (Böcker et al. 2017; Da Roit \& Van Bochove 2017). According to a recent representative study by Hielscher et al. (2017), 11\% of German households with a dependent older person employ an LIMC. With 2.1 million older people receiving LTC insurance benefits at home, approximately 200,000 LIMC arrangements are currently existing in Germany. By contrast, it is estimated that less than 1000 older dependents in the Netherlands make use of an LIMC arrangement (Da Roit \& Van Bochove 2017; Van Bochove et al. 2017; Van Grafhorst 2014).

The dominant mode of employing LIMCs in Germany is through informal arrangements between families and LIMCs (Kniejska 2016). As argued by Lutz and Palenga-Möllenbeck (2010), the German state has become an accomplice in theemergence and establishment of a largeinformal care sector by "knowing and pretending ignorance at the same time; acting officially in a restrictive way, while tacitly accepting the violation of self-made rules" (p. 426). Indeed, a solid legal basis for sanctioning employers was established with the 2004 Law Against Illegal and Irregular Employment (Gesetz zur Bekämpfung der Schwarzarbeit und illegalen Beschäftigung). Nevertheless, there have been very few investigations of the private household sector (Scheiwe 2010). The main reason for private households being rarely accused, is that workkplace inspections as a measure to detect irregular employment are largely limited to the country's construction and catering industry, two other sectors well known for irregular employment. In other words, despite the official rhetoric and available legal sanctions against employers, there is little political will to intervene in the private household sector. 
Parallel to this informal care market, a formal market for LIMCs has emerged, with placement agencies as a central actor (Rossow \& Leiber 2017). As calculated by the German consumer organisation and foundation Stiftung Warentest (2017), more than 250 LIMC placement agencies are active in the country. ${ }^{2}$ According to the spokesperson of an umbrella organisation, the Verband für häusliche Betreuung und Pflege e.V. (VHBP), ${ }^{3}$ around 30,000 households are currently using the services of these agencies. Commonly, the LIMC placement agencies cooperate with care service providers and/or temporary employment agencies in Poland, but increasingly also in other Eastern European countries such as Croatia, Hungary or Slovakia (Krawietz 2014). Like their counterparts in the black labour market, LIMCs usually commute between the household in Germany and the household in their country of origin for periods of between 1 and 3 months.

Initially, placement agencies primarily placed self-employed LIMCs in German households (Neuhaus et al. 2008), but more recently they have increasingly made use of the EU Posted Workers Directive (Stiftung Warentest 2017). This means that the LIMCs have a working contract with the employer in the sending country. In other cases, LIMCs are formally contracted by German families as home helps without the involvement of placement agencies. In this case, families act as employers and have to pay payroll tax and social security contributions for the LIMC. Depending on the type of emplyoment, costs can range from around 500 to 1800 euro per month for an irregularly employed LIMC (Kniejska 2015), and up to 3400 euro per month for an LIMC hired through a placement agency (Stiftung Warentest 2017).

Unlike in Germany, most users in the Netherlands hire their LIMCs through LIMC placement agencies. According to our mapping study, there are currently about 20 agencies active in the Netherlands, of which most were founded after 2010. Like in Germany, most of these placement agencies cooperate with temporary employment agencies or care services providers in Central and Eastern European EU member states. The care workers are recruited and often also employed (and then "posted" to the Netherlands)

\footnotetext{
${ }^{2}$ Most of the LIMC placement agencies operate at the local or regional level and are highly diverse with regard to staffing, number of clients, employment modes and cooperation models.

${ }^{3}$ In the VHBP, 35 of the largest LIMC placement agencies in the country are organised.
} 
International Journal of Ageing and Later Life

by these partners. However, there are also placement agencies that operate differently, for example, employing the LIMCs themselves and then placing them with clients in the Netherlands, asking their clients to act as employers or asking the LIMCs to work on a self-employed basis. The costs for the client amount to between 2500 and 3000 euro per month for one LIMC. A minority of the Dutch users recruit and employ their LIMCs themselves, without making use of the services of placement agencies. However, our assessment is that cases of informal employment are very rare in the Netherlands.

\section{Explaining Cross-Country Differences}

Cross-country variations in the prevalence of LIMC arrangements can be explained by different types of LTC regimes. As argued by this approach, different distributions of responsibilities between the state and the family shape the demand for LIMCs, in combination with migration and employment regimes (Da Roit \& Weicht 2013; Van Hooren 2014). Accordingly, the demand for LIMCs is assumed to be high in countries with low public expenditure on LTC, a large underground economy and extensive undocumented migration (Da Roit et al. 2007; Gori 2012; Van Hooren 2012). Medium demand for LIMCs is assumed for countries with low public expenditure on LTC, unregulated cash-for-care benefits and a high proportion of unskilled workers in the LTC sector (Da Roit \& Weicht 2013). Finally, the demand for LIMCs is assumed to be low in countries with high public expenditures on LTC, regulated cash-for-care benefits, a limited underground economy and a highly professionalised LTC sector (Da Roit \& Weicht 2013; Van Hooren 2012).

The first set of factors is characteristic for countries with familistic LTC regimes, like Italy or Spain (Bettio et al. 2006; Di Santo \& Ceruzzi 2010). Germany, together with Austria, is part of a group of countries combining the second set of factors. LTC regimes in these countries can be described as publicly supported private care regimes in which the family has remained the primary caring unit (Bettio \& Plantenga 2004). The Netherlands, Sweden and Norway represent countries combining the third set of factors (Da Roit \& Le Bihan 2010; Da Roit \& Weicht 2013; Van Hooren \& Becker 2012). In these countries, LTC is seen primarily as a public responsibility, and consequently, a high level of subsidies for using LTC services is provided (Lipszyc et al. 2012). A comparison of the 
German and Dutch LTC regimes shows that both countries maintained their position in this taxonomy but that convergence can be observed in policies aiming to promote home-based LTC arrangements.

As shown in Table 1, the Netherlands spend a far higher share of their GDP on LTC services than Germany (3.7\% vs. $1.3 \%)$. By contrast, private spending on LTC services is much higher in Germany. In 2008, copayments and direct out-of-pocket costs made up $32.9 \%$ of the expenditure on ambulatory and institutional care services in Germany, compared to less than $1 \%$ in the Netherlands (Lipszyc et al. 2012). Residential care for severe LTC needs puts an especially high financial strain on the budgets of German LTC recipients (Statista 2018). In light of this, it does not come as a surprise that according to a representative study, $54 \%$ of Germans would opt for an (informal) LIMC arrangement to avoid the high contributions to residential care (Bange \& Röthing 2007). With the last policy reform, the Pflegestärkungsgesetz 2 from 2017, German policymakers strengthened the existing system: whilst the maximum amount for cash benefits paid in case of informal home-based LTC was increased by $24 \%$, the maximum amount for in-kind allowances used for residential care remained virtually unaltered. In the Netherlands, on the other hand, user contributions for residential care have been raised considerably in the past few years, but the amount of the contribution depends on one's income and wealth, so

Table 1. The Dutch and German LTC regimes

\begin{tabular}{lcc}
\hline & Germany & Netherlands \\
\hline $\begin{array}{l}\text { Public LTC expenditure as share of GDP } \\
\text { Share of LTC recipients aged 65+ receiving } \\
\text { care at home, 2015 (2005) }\end{array}$ & $1.3 \%$ & $3.7 \%$ \\
$\begin{array}{l}\text { Share of LTC recipients aged 65+ receiving } \\
\text { only cash benefits }\end{array}$ & $59 \%(64 \%)$ & $71 \%(65 \%)$ \\
$\begin{array}{l}\text { LTC beds in institutions and hospitals } \\
\text { per 1000 population aged 65+, 2015 }\end{array}$ & 54.4 & $4.7 \%^{3}$ \\
LTC workers per 100 people aged 65+, 2015 & 1.9 (home) & 3.2 (home) \\
\hline
\end{tabular}

Sources: ${ }^{1}$ OECD 2017; ${ }^{2}$ Statistisches Bundesamt 2017, own calculations; ${ }^{3}$ Centraal Bureau voor de Statistiek 2018, PGB, LTC recipients 65 and older. 
International Journal of Ageing and Later Life

that residential care remains financially accessible for LTC recipients in all income groups.

In both countries, a similar and increasing share of LTC recipients receives care at home. However, whilst in Germany, $66 \%$ of these LTC recipients are cared for by family carers only (Statistisches Bundesamt 2017), their Dutch counterparts are much more likely to receive support from professional home care and/or household help services. The Dutch LTC system has undergone substantial reforms over the past few years. Only people who need constant care or supervision are entitled to benefits under the new LTC Act (Wet langdurige zorg). Simultaneously, the responsibility for organising the care for people with lighter care needs has been decentralised to local authorities under the new Social Support Act (Wmo 2015). One of the aims of this decentralisation was to foster the replacement of (publicly subsidised) household help and other professional care services by informal care. However, recent research shows that this aim has not been realised (Bredewold et al. 2018). There appears to be a discrepancy between, on the one hand, the underlying premises of the recent and ongoing LTC policy reforms and, on the other hand, the trend in care ideals among the population, which at least until recently was towards, rather than away from, care ideals in which the family has only a very limited responsibility for the provision of care for the frail old (Van den Broek 2016).

The German LTC insurance promotes family-based LTC arrangements through a combination of strict eligibility criteria for residential care and largely unregulated cash benefits (Pflegegeld). The cash benefit is paid directly to the dependent person with no need to provide proof of its use, making it relatively easy to spend the money on hiring an LIMC. However, depending on the degree of dependency (Pflegegrad), cash benefits range from 316 to 901 euro per month and do not cover the entire costs for an LIMC arrangement as mentioned in the previous section. Nevertheless, for more than $50 \%$ of LTC recipients aged 65 and older in Germany, the Pflegegeld is the only benefit received from the LTC insurance. If only those are looked at who are cared for at home, the share even increases to $81 \%$, indicating that in many private households, LTC is provided informally.

By contrast, in the Netherlands, only $4.7 \%$ of LTC recipients aged 65 and over received a cash benefit [persoonsgebonden budget (PGB)] under the 
new LTC Act in 2016 (Monitor Langdurige Zorg 2018, own calcuations). The difference is even more remarkable as the average monthly cash benefit in the Netherlands is significantly higher than that in Germany (3400 euro) (Sociale Verzekeringsbank 2016; see also Mosca et al. 2017). The low propensity of Dutch LTC recipients to opt for cash benefits can be explained in part by the comparatively generous in-kind allowances and in part by the tight regulation and supervision of these payments ( $\mathrm{Da}$ Roit \& Le Bihan 2010). Unlike in Germany, the money is not paid directly to the dependent person and application and reimbursement procedures involve a lot of paperwork (Mot 2010; Sadiraj et al. 2011). The regulation of cash benefits impedes Dutch LTC recipients from using the money to informally employ an LIMC and helps explain why LIMCs in the Netherlands are hired through a placement agency, if they are hired at all (Da Roit \& Van Bochove 2017).

Table 1 shows that the number of LTC beds in the Netherlands is much higher than in Germany. Nevertheless, there has been a clear trend away from residential care. Whilst in 1995, 25\% of the Dutch population aged 80 years and older were residing in residential care homes, the proportion dropped to only 12\% in 2017 (Centraal Bureau voor de Statistiek 2018, authors' own calculations). This development can be seen as the outcome of a change in preferences away from residential care and towards home-based care both among policymakers and among older people themselves. To reduce LTC expenditures, Dutch policymakers made the promotion of home-based and informal care arrangements an explicit policy goal (Grootegoed et al. 2015; Mot et al. 2010; Tonkens 2011). Deinstitutionalisation has clearly been more successful than deprofessionalisation. However, there are signs that the trend towards deinstutionalisation is reaching its limits. There is an increasing concern that home-based care does not or cannot fulfil the care needs of a growing group of vulnerable older people who, until recently, would have (been) moved to a residential care home. At the same time, concerns about the quality of residential care (especially the lack of personal attention) have resulted in large amounts of money being reserved to secure and improve it.

In Germany, the ratio of LTC workers (in home-based as well as institutional care) to the population aged 65 and older is much lower than in the Netherlands. This difference also reflects the acute shortage of LTC workers in Germany, which is inextricably linked to the difficult working 
International Journal of Ageing and Later Life

conditions in this sector characterised by relatively low pay and a high work load. Understaffing adds to broader criticism towards residential care homes in Germany, including the prioritisation of organisational rationalities, particularly cost-effectiveness, at the expense of a more individualised care approach, the dominance of the medical paradigm at the expense of the social and emotional aspects in care and an increasingly visible standardisation of care (Behr 2015; Greß \& Stegmüller 2016). Concerns about the quality of care provided in residential care homes are nurtured by media reports and studies about abuse and neglect (MDS 2017; ZQP 2017). Often reinforced by biographical experiences, these concerns fortify a widespread "institutionalisation aversion" (Costa-Font 2017) and partly explain the high moral pressure to arrange home-based LTC in old age. However, the high value placed on home-based LTC arrangements puts considerable burdens on family carers, with several studies revealing the negative impact of their situation on their social and physical well-being along with financial constraints (Bestmann et al. 2014; Pinquart 2016).

\section{Data and Methods}

This study is part of the comparative research project "The Emergence and Significance of Transnational LTC Arrangements in Germany and the Netherlands." To gain insights from various angles, semi-structured interviews with different actors involved in LIMC arrangements (e.g. family members, care recipients and LIMCs) were conducted between May 2016 and March 2018 in both countries. The main selection criterion for households was the current or earlier employment of an LIMC. Family members were selected according to their role as primary family carers who as such were involved in various forms of support, including administrative tasks as well as caring activities. For the Dutch part, the study was reviewed and approved by the Ethics Committee Faculty of Law/Nijmegen School of Management of Radboud University Nijmegen (registration number 2016.11). For the German part, no ethical approval was requested by the Johannes Gutenberg University Mainz.

To explore the families' motivations and justifications for using an LIMC arrangement, we analysed 39 interviews (including follow-up interviews) with 14 primary family carers in Germany and 10 primary family carers in the Netherlands. Follow-up interviews were conducted to clarify questions 
and capture changes in the LIMC arrangement over time. The initial aim was to interview the care recipients as well. However, oftentimes, this was not possible due to cognitive and/or health impairments. The same interview guideline was used in both countries, covering four broad themes: (1) reasons for establishing an LIMC arrangement, (2) structure of the arrangement (e.g. mode of employment, duration, etc.), (3) everyday care activities and (4) assessment of care provided. The interviews took place at the respondents' place of choice, with some preferring the care recipients' household and others being more comfortable in a different location.

In both countries, respondents were primarily the children of the care recipients. In Germany, the children were in their 50s and 60s and varied considerably regarding their socio-economic profiles and family situation. Some lived in the same house as their parent, whilst others lived several hundred kilometres away. The latter periodically moved into their parents' house to either support or swap with the LIMC. In the Netherlands, the children were of a similar age as their German counterparts, their family situation varied, but they were less heterogeneous in terms of their socioeconomic profiles and geographic location. The majority was higher educated, employed full-time and lived less than $20 \mathrm{~km}$ away from the care recipient. In three cases in Germany and two in the Netherlands, the family carer was the care recipient's spouse or partner. All German spouses were males in their 70s and had cared for their wives for several years by themselves before taking the decision to employ an LIMC. The Dutch spouses were women of working age with a demanding job and/ or study.

Field entry and sampling was difficult in both countries, although for different reasons. In the Netherlands, the main obstacle was that LIMC arrangements are still rare, and consequently, chain referrals were of little use. Most respondents could only be recruited via LIMC placement agencies, using a clustered sampling technique. In a few cases, the care recipient was already deceased at the time of the interview or the family carer had quit the arrangement for a variety of reasons. By contrast, in Germany, the main obstacle was the respondents' reluctance to participate because of the irregular employment situation of the LIMCs. Snowball sampling through personal contacts was therefore particularly useful to find interview participants. Key informants from LTC services were also 
International Journal of Ageing and Later Life

helpful in establishing contact with family carers but often perceived our request as an additional burden. Attempts to recruit respondents through care associations, parishes, placement agencies and through a Facebook site proved to be of little success. Altogether, in eight care arrangements in Germany, the LIMCs were employed irregularly, in five placed by an agency and in one case, the LIMC was directly employed by the family.

In both countries, all LIMCs came from Central and Eastern European EU member states. In Germany, the majority came from Poland and some from Romania and Slovakia. In the Netherlands, the majority came from Slovakia. Others came from Romania, Poland, Bulgaria and Hungary. At the time of data collection, all but one of the LIMCs employed by Dutch and German families were women. Their age ranged from 30 to nearly 70 years, with an over-representation of women in their 40s and 50s. Most were married and had a husband and children living in their country of origin. The women's educational background was very diverse. They usually completed secondary education and were trained in very different professions (e.g. accountant, craftswoman and teacher). Only very few were trained as nurses, and some who were employed by an agency received a crash course in caring before taking up their first job. Thus, most caring knowledge was based on experiences with frail and older family members. Many had worked for several German or Dutch families already and considered themselves fairly well prepared for this job.

Data collection and analysis was done in Dutch and German and all interviews were audio-recorded and transcribed verbatim. We used a twostep analysis for the empirical data. Firstly, we analysed each case as a whole, to reconstruct the narrative of motivations and justifications in the context of its particular constraints and opportunities. In this step of the analysis, we focused on how primary family carers made sense of their choice for an LIMC arrangement, including both objective aspects (such as specific events, health deterioration and financial constraints) and subjective ones (arguments, care ideals, preferences and values) behind the decision. Secondly, we analysed interviews thematically, using a combination of inductive and deductive codes. Based on our research questions, we searched the data for answers to three sets of questions: (1) concrete reasons triggering the choice for using LIMCs, (2) aims and motivations of family carers and (3) justifications for establishing a transnational care arrangement. Within each of these questions, we identified recurrent 
individual arguments, which were grouped into themes. Throughout this process, the interviews of the Dutch and German cases were analysed separately, and subsequently results were compared to identify differences and similarities. Finally, we tried to make sense of the cross-national differences, by setting different motivations and justifications against the national institutional framework of LTC regimes.

\section{Reasons and Motivations}

In both countries, the main triggers that lead to an LIMC arrangement were changes that required a modification in the actual care of the care recipient. The need to look for different care arrangements emerged from a deterioration of the care recipient's health condition, be it by an aggravation of a condition such as dementia, Parkinson's disease, stroke, old-age frailty and/or a combination of these, or by sudden crisis events such as the death of the care recipient's spouse or a fall with serious injuries. The previous care arrangement, usually involving a combination of informal and ambulant home care and/or day care services, became unfeasible, or a living arrangement in the private home without the provision of care was no longer possible.

\section{Preventing Residential Care}

In both countries, the search for a new care arrangement was conducted with the principle aim to prevent the care recipient from having to move to a residential care home. This aim was based on two closely linked factors. One was the care recipient's wish to stay at home and the family carers' desire to meet this preference. The other resulted from the negative associations of care recipients and family carers about residential care homes, especially among respondents in Germany. Rather than as an alternative, residential care homes were perceived as a last resort, a measure to be taken only when all other possibilities have been exhausted. Accordingly, avoiding the worst case was the starting point of the family carers' search for solutions. As put by one care recipient's son: "The focus was always that he shouldn't move to a residential care home. And then I looked, how can we do that?"

For the German interview partners, a strongly internalised responsibility and a felt moral obligation to care for a spouse (or parent) oneself were 
International Journal of Ageing and Later Life

closely related to the preference for home care and for avoiding residential care, as illustrated by the following quote of a caregiving husband:

As I said, I feel committed to her. I also said, okay, that's my wife and that's just what she is, right? And that's the way it is, I don't know why. But if I had to put my wife into a residential care home today, that would be really hard for me. PN7, spouse of care recipient, middle level education, secondary

In this respect, hiring a migrant care worker does not only allow for the care recipient to stay at home, but is also a way to deal with the inner turmoil of the German family carers who feel overburdened but uncapable to move their dependent relatives into a residential care home.

For the Dutch family carers, too, the principal aim was to enable the care recipient to stay at home. However, their arguments were different from those of the German respondents. Not all had a negative image of residential care in general. Instead, they emphasised that it would not be a suitable option for their parent or spouse. For example, a son who had moved his older parents back home from a residential care home explained: "I had the feeling - despite the good care and the good intentions of the people that were looking after them - that they were depressed." Other respondents pointed out that the care recipient had never felt comfortable in a group or that he or she had always attached great value to having autonomy and being able to pursue his or her own lifestyle. The arguments of the Dutch respondents thus referred more to the (individual) perspective of the care recipient.

\section{A More Personalised, Holistic and Stable Provision of Care}

Both German and Dutch family carers emphasised that opting for an LIMC arrangement was closely linked with their preference for a more personalised and holistic provision of care. They agreed that this type of care could not be delivered in residential care homes due to poor staff to care recipient ratios and high turnover rates. Personnel continuity also played a role when deciding against other possible LTC arrangements, for example, those involving ambulant care services. Constantly changing ambulant care workers were thought to have a destabilising effect on the care recipient's mood, causing aggressive and rebellious behaviours, 
as the son of a Dutch care recipient said. With the stable presence of an LIMC, the care recipient would become more calm and balanced. Generally, family carers in both countries appreciated personnel continuity and the development of trustful, family-like relationships between the care recipient and the LIMC.

\section{Lowering Family Care Burdens}

Besides the preference for a stable and individualised care arrangement, German family carers in particular sought to reduce their organisational effort by employing an LIMC. Particularly those with competing commitments (e.g. work, children) often had to search for a quick, stable and uncomplicated solution to their relatives' need for around-the-clock care and supervision. Most found it very challenging to combine different care services (e.g. ambulant care service, day care centres) and technologies (e.g. in-house emergency call system) into a continuous and gapless care arrangement. This aim figured less prominently in the accounts of the Dutch respondents. However, several sons and daughters also pointed out that if they had wanted to make things really easy for themselves, they would have sent their parent to residential care. As one of them explained, "Once you have moved your parents to a care home, you only have to visit them now and then."

Another related difference was found regarding the role of caring responsibilities as part of the German and Dutch families' decision to establish an LIMC arrangement. For German family carers, reducing their care burden was a much stronger motivation for employing an LIMC than for their Dutch counterparts. Whilst some German family carers relatively quickly acknowledged that they were overburdened, others only subsequently accepted "that there seemed to be a limit" to the care load they could manage. This was primarily the case in care constellations involving spouses. A sense of obligation together with the belief that the spouse is the most appropriate caregiver for the partner in need of care made some spouses hesitate to accept temporary relief from other care providers. This seemed to be more characteristic for the German than the Dutch respondents.

This difference may be explained by the German respondents actually bearing a higher care burden. German family carers seemed to be more frequently involved in daily care activities such as personal hygiene, 
International Journal of Ageing and Later Life

dressing or feeding. Dutch respondents, in contrast, were more likely to take on the roles of "care managers" (Degiuli 2010). When asked which care tasks they performed for their parent or partner, most of our Dutch respondents referred to the organisation of the care, administrative tasks (in particular managing their parent's or partner's LTC cash benefit) and the provision of emotional support. Our German respondents mentioned hands-on care and help more often.

That more German respondents reported feeling overburdened can at least partly be related to differences in the availability and use of LTC services in the two countries. Some German family carers employing an LIMC made additional use of care services such as day care centres, ambulant care services or volunteers. However, unlike in the Dutch case, the use of additional care services or household workers in German families was closely linked to their socio-economic resources. In the Netherlands, families are required to a lesser extent to draw on their own resources, due to the wider availability of publicly subsidised care services like household help and day care, which are administered by local authorities. These services are relatively easy to access, but they only suffice for older people with relatively light care needs. Once care recipients start to need around-the-clock care or supervision, they are referred from the Social Support Act to the LTC Act, which normally implies a move to a residential care home. In practice, it is impossible to organise 24/7 care at home with regular LTC service providers. Various Dutch family carers reported that they were disappointed to discover this.

\section{Justification for Employing a Live-in Migrant Care Worker}

Even though our respondents in both countries felt that LIMCs were the best available option to meet the care needs of their family members, this option was not per se an unquestioned alternative and it required justifications on various levels.

\section{A Widespread Practice vs. Pioneering}

A striking difference between the two countries was found with respect to the justifications given by respondents for using an LIMC arrangement. Various German family members reported that employing an LIMC was 
recommended to them by health insurance workers or social assistants. In one case, professionals even provided them with brochures of placement agencies. Others pointed out that family members, friends or neighbours influenced their decision, and on occasion even convinced them to establish an LIMC arrangement. Altogether, the findings indicate that in Germany, it is a widely accepted social practice to employ an LIMC, regularly or irregularly. In other words, whilst German family carers would have to justify (to others and to themselves) bringing their dependent relatives to a residential care home, they do not feel the need to justify the decision for using an LIMC arrangement.

By contrast, various Dutch family carers reported that opting for an LIMC arrangement was by no means an obvious or uncontested choice. Only a few Dutch respondents knew other people who made use of an LIMC arrangement. In a sense, they were "pioneers" or "early adopters," as the staff members of some placement agencies characterised their clients. As such, they are breaking new ground in the Dutch LTC system, and therefore, are faced with a different type of legitimation pressure than their German counterparts. Several Dutch respondents saw themselves as people who swam against the current, because they had acted against the advice of the family doctor or other care professionals to bring their parent or spouse to a nursing home. Their accounts show that in the Netherlands, residential care is still the "default option" for older people who need more or less constant supervision and help or care.

\footnotetext{
If the family doctor advises admission to nursing home, then it is very easy for the children to say: yes, let's just do that. Because if someone with knowledge and expertise tells you to do so, why not do that? Your father or mother may say: but I want to stay in my own home. - Yes, but that is impossible, you cannot stay here on your own, and we have a place in a nursing home now, let's just do that. And what does he say then, so as not to be a burden to his children: yes, then let's do it. But will he be happy then? C5, son of care recipient, high level of education (tertiary)
}

Moreover, several Dutch respondents reported disagreement within the family and the need to justify their decision to hire LIMCs, as other family members had a preference for "professional" carers. Although not frequently, they also received negative reactions from their social network where people put the legality or moral legitimacy of such an arrangement into question. 
International Journal of Ageing and Later Life

\begin{abstract}
I told a colleague at work how I had arranged this - and this colleague had just brought her mother to a nursing home, she was in the same situation as me - and she almost lashed out at me: how could I do that, that was exploitation, social exploitation! C0, daughter of care recipient, high level of education (tertiary)
\end{abstract}

Apart from this difference, family carers in both countries justified their decision for employing an LIMC by the lack of alternatives. Other arrangements for providing around-the-clock care and supervision at home were seen as too complex to organise, too costly or simply not available. For instance, the very high costs for an around-the-clock care arrangement with regular home care providers were mentioned by German and Dutch family carers alike. A German respondent reported that for only an 8-hour shift, he received a cost estimate from a home care provider of about 4000 euro per month. Similarly, respondents in the Netherlands reported very high monthly costs (12,000-15,000 euro) exceeding most families' income.

\title{
Justifying Working Conditions
}

The LIMCs' working conditions are much more unfavourable than those of regular German or Dutch home care workers. In both countries, the LIMCs' pay is based on a 40- to 48-hour work week. It is challenging for family members and/or care recipients to develop specific arguments and practices to legitimise the fact that the carers are not paid for being on call many more hours. One strategy consists of downplaying the burden of presumed difficult working conditions. In this respect, we found arguments that justified their relatively low pay by arguing that LIMCs do not have to work all the time, that they get free board and lodging and that they earn much more than what they could earn in their country of origin.

Regarding the question of what should be considered as work and what as leisure time (e.g. having breakfast with the care recipient, being on call at night), family carers provided very similar justifications to the ones used by placement agencies. According to Schwiter et al. (2018), placement agencies construct discursive boundaries between working time and being present (not defined as work) to justify the incongruence between the contractually agreed 40 or 48 hours working week and the constant availability expected of the LIMC. Downplaying the LIMCs' work load was also a common justification, especially among German family 
carers. These family carers often also claimed that the working conditions of their carers compared favourably with those of migrant carers in other families.

As far as the working conditions are concerned I think - it sounds almost presumptous - but in principle it is a very nice house, it is generous. One can withdraw, one can also go out for an hour or two. In other situations, in other care contexts, this is impossible, right? PN13, daughter in law of care recipient, higher level education (tertiary)

Some German and Dutch family carers went beyond justifications and took action to improve their LIMCs' working conditions. Some of the Dutch family carers negotiated with the placement agency to obtain a higher pay for their LIMC or switched to another agency. One family carer terminated the contract with the placement agency and started to recruit and hire LIMCs himself. However, most family carers were not prepared to go that far, among other reasons, because the placement agency provided good quality care and/or continuity of care: "So, I disapprove of [the gap between what the carer and what the agency gets], but, you know, they offer good quality and I have a carer now."

In addition, in both countries, we found families hiring a second migrant care worker in intensive care situations. Care recipients with disturbed day and night rhythms and/or high mobility needs pose a challenge to a single migrant care worker and this may increase the risk of a premature termination of the arrangement. Through the employment of an additional migrant care worker, families lowered the individual care load and ensured the continuity of around-the-clock homebased care. A few families in the Netherlands were able to finance this option by applying for a new care needs assessment, resulting in a raise of the care recipient's cash benefit. In Germany, this option is only available to relatively few financially solvent families. Families with more limited financial opportunities who acknowledged the strains of the job also sought to reduce the migrant care workers' burden by creating a mix of informal and formal care providers. Accordingly, LIMC arrangements were often part of a larger care mix involving family carers, neighbours, outpatient care services, day care centres, community services, etc. 
International Journal of Ageing and Later Life

Type of Employment: Informal Employment vs. Employment Through an Agency

As described above, LIMCs are employed in different ways in the two countries. In Germany, to a large extent, the carers are hired informally. This is also reflected in our German sample, where migrant care workers were mostly hired on an informal basis. By contrast, in the Netherlands, LIMCs are mainly hired through placement agencies. The justifications given by the German and Dutch respondents for the mode of employment of their LIMCs were therefore correspondingly different.

German families employing an LIMC informally may feel compelled to legitimise their decision. Financial aspects played a role in this regard but perhaps not as one would expect. Whilst some mentioned that employing an LIMC directly or through a placement agency exceeded their financial possibilities, others argued that the LIMC preferred to be informally employed in order to receive a higher net income. Placement agencies were blamed for charging very high fees whilst only paying little to the migrant care workers: "They earn a lot of money at the expense of the migrant carers who do the work." By criticising the apparently unethical practices of placement agencies, family carers construct themselves as morally superior, giving their own informal practices a positive connotation. That many other families also employed an LIMC informally strengthened some respondents' belief that the state tolerated this practice to prevent the breakdown of the German LTC system: "I gave thought to it but so far it has gone well. Like in the case of hundred thousand others as well...And I say, the state tolerates it. Without it, care in old age would be impossible."

Although most Dutch family carers hired their LIMC through placement agencies, many of them were not confident about the legality of their LIMC arrangements. They did not know or understand the EU posting of workers' rules and doubted whether their placement agency complied with all relevant laws and regulations. In a few cases, these doubts were fuelled by negative reactions from the respondents' social network. The justifications of these family carers for why they continued to hire migrant carers were typically couched in terms of responsibility. They argued that they could not be held responsible for ensuring proper working conditions because they were only buyers of care services and their first 
priority and responsibility was that their relatives received good care. In these respondents' view, the placement agencies have prime responsibility for the working conditions and the state should control the agencies. As one family carer said, "As the state has made a mess of the care system, they have a responsibility here as well." Another family carer told us about a conversation he had with the administrative agency that organises the LTC in his region:

I asked: does nobody look at how this company [placement agency] works? - No, nobody. I asked: who should do this? - You have to do that. I said: I am not Sherlock Holmes, I cannot do that, that is not my job. I think that if the government grants this money, there should be a kind of inspecting body, but there is not. C1, son of care recipient, high level of education (tertiary)

In summary, family carers in both countries feel different needs to justify their making use of an LIMC arrangement. The norm of professional LTC in the Netherlands has a bearing on how Dutch family carers have to justify their decision to their social environment as well as to themselves. To justify the LIMCs' working conditions, they refer to the responsibility of the placement agencies and the state to ensure Dutch working standards. German family carers also refer to placement agencies and the state, although for different reasons. They refer to the apparently abusive practices of placement agencies and the state's failure to provide affordable quality care to justify why they employ their migrant carers informally.

\section{Conclusion and Discussion}

We started from the observation of the different scope and features of LIMC arrangements in Germany and the Netherlands. Whilst these arrangements are widely used in Germany, they are (still) a small-scale phenomenon in the Netherlands. We explained this difference by the different configurations of LTC regimes in the two countries. In Germany, social norms of family responsibility are reflected in the country's LTC policies that prioritise informal over institutional care. Accordingly, relatively low but unregulated cash-for-care benefits foster informal care arrangements and facilitate the employment of LIMCs. Germany's laissez-faire policy towards irregular employment of LIMCs in private households notably 
International Journal of Ageing and Later Life

contributes to this development. In addition, high co-payments and serious concerns about the quality of care provided make residential care homes neither an affordable nor a desired option for many German family carers and their relatives in need of care.

In the Netherlands, residential care is the default option in case of heavy care or supervision needs in old age, despite a recent policy trend towards deinstitutionalisation and deprofessionalisation. In fact, policy efforts to deprofessionalise LTC have not led to a substantial change in the country's professional LTC infrastructure. Dependent older people can still draw on a broad range of available and affordable LTC and home help services, enabling family carers to maintain their role as care managers rather than becoming providers of hands-on care. Although cash-for-care benefits are relatively high in the Netherlands, they are tightly regulated and supervised. Together with the availability and affordability of other options, this seems to discourage family carers from more widely opting for cash-for care benefits, as indicated by the very small proportion of older people receiving these payments. Moreover, it can be assumed that their tight regulation and supervision disincentivises the development of a black labour market for LIMC arrangements.

Our empirical analysis of interviews with primary family carers in the two countries has shown how the different LTC regimes in Germany and the Netherlands affected family decision-making. Although family carers in both countries explained the decision for an LIMC by their preference for a home-based care arrangement, they took their decision for different reasons. The decision of German family carers to employ an LIMC was primarily triggered by the aim to avoid moving the care recipient to a residential care home and to reduce their own care load. Moreover, by employing an LIMC, they did not challenge the social norm of family-based care in old age, in that the arrangement remained in the private sphere. At the same time, it offered a way to deal with the structural constraints inherent to Germany's LTC regime, which places a high responsibility on the family and consequently leads to the overburdening of (many) family carers. Aditionally, due to the social norm of home-based LTC in old age and the widespread use of LIMC arrangements, German family carers felt little pressure to justify their decision for using this kind of care arrangement, including the employment of LIMCs on an irregular basis. 
By contrast, in the Netherlands, the decision to employ an LIMC was linked much more to the care recipients' specific needs than to an overburdening of family carers and the rejection of institutional care. In this sense, LIMC arrangements represented an extended option of LTC in old age tailored to the individual needs and not an escape route from a structural dilemma as in the German case. However, due to the high acceptance of institutional care, the norm of professional LTC services and the novelty of LIMCs, Dutch family carers were more likely to have to justify their decision to their social environment as well as to themselves.

Another striking difference between Dutch and German family carers lies in their expectations towards public authorities in ensuring working conditions compliant to labour law. Whilst German family carers saw themselves as the main actors responsible for creating (in their view) decent working conditions, Dutch family carers referred to the responsibility of the placement agencies and public authorities to ensure Dutch working standards. When German family carers referred to placement agencies and public authorities, it was for a very different reason. They referred to the abusive practices of placement agencies and the state's failure to provide affordable quality care to justify why they employed their migrant carers informally. In sum, the Dutch and German LTC regimes impact differently the decision-making processes of families as well as on patterns of justification through a combination of policies and social norms and the related expectations towards care and care work in old age.

Several questions arise regarding the future development of the scope and configuration of LIMC arrangements in Germany and the Netherlands. Will the political laissez-faire attitude towards irregular employment of LIMCs in Germany continue? How sustainable is this approach in view of changes in the sending countries and a rapidly ageing population? As far as the first question is concerned, irregular LIMC arrangements are not an urgent issue on the political agenda in Germany. Policymakers are well aware that inspections and regularisation measures would increase the costs for employing an LIMC through fines and higher wages. Families not able to afford the additional costs would have to fall back on alternative care resources to fill the resulting care gap. An even stronger reliance on family carers and a growing demand for places in already understaffed residential care homes would be a probable scenario. 
International Journal of Ageing and Later Life

Public pressure on policymakers to relieve family carers' burden and improve the working conditions and care quality in residential care homes would presumably lead to unpopular policy reforms in order to broaden the income base of the LTC insurance. Briefly put, LIMC arrangements are cost-effective for the Geman government and relieve it from the necessity to develop solutions for the deficits in LTC provision for older people.

The recent increase of cash benefits in Germany has certainly brought some financial relief to LTC recipients and their families. However, several family carers interviewed reported requests for higher salaries from irregularly employed LIMCs during the last 2 years. Although the relationship between the two developments is not clear, macro-structural changes may influence the negotiations between private households and LIMCs. The request for higher salaries may also indicate an increasing shortage of labour supply and/or improved bargaining power of LIMCs. Indeed, the unemployment rate in Poland, the main source country of LIMCs in Germany, decreased considerably since the 2008-2012 global recession (Eurostat 2018). The relatively high average age of Polish LIMCs (Krawietz 2014) further suggests that the younger generation are not necessarily going to follow their mothers' and grandmothers' path. This trend has been confirmed by different managing directors of placement agencies who recruit their personnel increasingly from other Eastern European countries. They also reported difficulties to place LIMCs in households in areas with less developed infrastructures, especially in rural areas. Altogether, this indicates that there is no certainty about the sustainability of these arrangements as a fundamental pillar of the German LTC regime.

It is equally difficult to predict whether LIMC arrangements will become more widely used in the Netherlands. On the one hand, the shift in preferences from residential to home-based care and the impossibility of organising around-the-clock care at home with regular LTC services might well make LIMC arangements a potentially interesting option for a growing number of families. Moreover, the relatively generous Dutch LTC cash benefits would make it an affordable option for a large number of families. Cash benefits were a late addition to the Dutch LTC system, and it is still much more common to make use of in-kind benefits. However, the accounts of the Dutch respondents indicate that the barriers to opting for cash benefits and LIMCs are lower if LIMCs can be hired 
through placement agencies, which, in the perception of potential clients, are not that different from other private home care providers.

On the other hand, social and moral norms about how and by whom LTC for frail old people should be provided may be a more important barrier. Family carers in the Netherlands experience strong pressures to opt for residential care and "professional" carers when the care needs of their relatives increase. Moreover, to the extent that there is public or political debate about the use of LIMC arrangements, they tend to be seen as exploitative and as contributing to the displacement of Dutch care professionals rather than as a potential solution for deficits in the existing LTC system. Although the number of LIMC placement agencies in the Netherlands is only a fraction of that in Germany, Dutch parliamentarians have already asked critical questions about these agencies' practices. Overall, it is seems very unlikely that Dutch authorities would get away with a laissez-faire attitude towards large-scale informal employment of LIMCs like in Germany or, for that matter, tolerate irregular practices of LIMC placement agencies.

\section{Acknowledgements}

This research has been enabled by research funding from the German Research Foundation (DFG) and the Netherlands Organisation for Scientific Research (NWO) in the framework of the Open Research Area (ORA) for the social sciences [the project "Emergence and Significance of Transnational Elderly Care Arrangements" (ESTRANCA)].

\section{Corresponding Author}

Vincent Horn, Institute of Education, Johannes Gutenberg University Mainz, Jakob-Welder-Weg 12, 55128 Mainz, Germany. Email: hornv@unimainz.de

\section{References}

Anderson, A. (2012). Europe's care regimes and the role of migrant care workers within them. Journal of Population Ageing 5(2): 135-146.

Bange, T. \& Röthing, I. (2007). Qualität ja, aber nicht um jeden Preis [Quality yes, but not at any cost]. Wohlfahrt Intern 9: 8-11. 
International Journal of Ageing and Later Life

Behr, T. (2015). Aufbruch Pflege: Hintergründe - Analysen - Entwicklungsperspektiven [Departure Care: Backgrounds - Analysis - Development Perspectives] Wiesbaden: Springer Gabler Verlag.

Bestmann, B., Wüstholz, E. \& Verheyen, F. (2014). Pflegen: Belastung und sozialer Zusammenhalt. Eine Befragung zur Situation von pflegenden Angehörigen [Caring: Burden and Social Cohesion. A Survey on the Situation of Family Caregivers]. Hamburg: Techniker Krankenkasse.

Bettio, F. \& Plantenga, J. (2004). Comparing care regimes in Europe. Feminist Economist 10(1), 85-115.

Bettio, F., Simonazzi, A. \& Villa, P. (2006). Changes in care regimes and female migration: The "care drain" in the Mediterranean. Journal of European Social Policy 16(3): 271-285.

Bettio, F. \& Verashchagina, A. (2012). Long-Term Care for the Elderly. Provisions and Providers in 33 European Countries. Luxembourg: Publications Office of the European Union.

Böcker, A. G. M., Horn, V. \& Schweppe, C. (2017). Old age care regimes and the emergence of transnational long-term care arrangements for the elderly. In L. Good Gingrich \& S. Köngeter (eds.), Transnational Social Policy, Social Welfare in a World on the Move (pp. 222-242). New York: Routledge.

Bredewold, F., Duyvendak, J. W., Kampen, T., Tonkens, E. \& Verplanke, L. (2018). De verhuizing van de verzorgingsstaat. Hoe de overheid nabij komt. Amsterdam: Van Gennep.

Cangiano, A. (2014). Elder care and migrant labor in Europe: A demographic outlook. Population and Development Review 40(1): 131-154.

Centraal Bureau voor de Statistiek (2018). Personen in huishoudens naar leeftijd en geslacht [Persons in Households by Age and Gender]. Available on http:/ / statline.cbs.nl/Statweb/publication/?DM=SLNL\&PA=37620 $\& D 1=0-1,11 \& D 2=0 \& D 3=0,66-96 \& D 4=0,5,10,21-23 \& H D R=G 3, T \& S T-$ $\mathrm{B}=\mathrm{G} 1, \mathrm{G} 2 \& \mathrm{VW}=\mathrm{T}$ (Accessed: May 15, 2018).

Colombo, F., Llena-Nozal, A., Mercier, J. \& Tjadens, F. (2011). Help Wanted? Providing and Paying for Long-Term Care. Paris: OECD.

Costa-Font, J. (2017). "Institutionalization Aversion" and the Willingness to Pay for Home Health Care. CESifo Working Papers No 6703. Munich: Munich Society for the Promotion of Economic Research.

Da Roit, B., \& Le Bihan, B. (2010). Similar and yet so different: Cashfor-care in six European countries' long-term care policies. Milbank Quarterly, 88, 286-309. 
Da Roit, B. \& van Bochove, M. (2017). Migrant care work going Dutch? The emergence of a live-in migrant care market and the restructuring of the Dutch long-term care system. Social Policy \& Administration 51(1): 76-94.

Da Roit, B. \& Weicht, B. (2013). Migrant care work and care, migration and employment regimes: A fuzzy-set analysis. Journal of European Social Policy 23(5): 469-486.

Da Roit, B., Le Bihan, B. \& Österle, A. (2007). Long-term care policies in Italy, Austria and France: Variations in cash-for-care schemes. Social Policy Administration 41(6): 653-671.

Di Santo, P. \& Ceruzzi, F. (2010). Migrant Care Workers in Italy. A Case Study. Report presented for the project "Health system and long-term care for older people in Europe." Available on http://interlinks.euro. centre.org/sites/default/files/WP5_MigrantCarers_FINAL.pdf (Accessed: May 24, 2018).

Eurostat (2018). Unemployment Statistics, April 2018. Available on http:// ec.europa.eu/eurostat/statistics-explained/index.php/Unemployment_statistics\#Youth_unemployment (Accessed: May 10, 2018).

Finch, J. \& Mason, J. (1993). Negotiating Family Responsibilities. London/ New York: Routledge.

Gori, C. (2012). 'Home care in Italy: A system on the move, in the opposite direction to what we expect'. Health and Social Care in the Community 20(3): 255-264.

Greß, S. \& Stegmüller, K. (2016). Gesetzliche Personalbemessung in der stationären Altenpflege: Gutachterliche Stellungnahme für die Vereinte Dienstleistungsgewerkschaft (ver.di). [Statutory assessment of staff in in-patient care for the elderly: Expert opinion for the Vereinte Dienstleistungsgewerkschaft (ver.di)]. Fulda: pg-papers: Diskussionspapiere aus dem Fachbereich Pflege und Gesundheit 1/2016

Gress, S. \& Stegmüller, K. (2016). Gesetzliche Personalbemessung in der stationären Altenpflege [Statutory Assessment of Staff in In-Patient Care for the Elderly]. Fuda: Expert opion for the Vereinte Diensleistungsgewerkschaft (ver.di).

Grootegoed, E., Van Barneveld, E. \& Duyvendak, J. W. (2015). What is customary about customary care? How Dutch welfare policy defines what citizens have to consider "normal" care at home. Critical Social Policy 35(1): 110-131. 
International Journal of Ageing and Later Life

Hielscher.V., Kirchen-Peters, S. \& Nock, L. (2017). Pflege in den eigenen vier Wänden: Zeitaufwand und Kosten [Care in the privacy of one's home: Expenditure of time and costs]. Hans-Böckler-Stiftung, Düsseldorf: Study Nr. 363.

Kniejska, P. (2015). All-inclusive-Pflege aus Polen in der Schattenzone [All-Inclusive-Care from Poland in the Shadow Zone]. In: WISO direkt. May 2015. Bonn: Abteilung Wirtschafts- und Sozialpolitik der Friedrich-Ebert-Stiftung

Kniejska, P. (2016). Migrant Care Workers aus Polen in der häuslichen Pflege: Zwischen familiärer Nähe und beruflicher Distanz [Migrant Care Workers from Poland in Home-Based Care: Between Family Proximity and Professional Distance]. Wiesbaden: VS Verlag für Sozialwissenschaften.

Krawietz, J. (2014). Pflege grenzüberschreitend organisieren. Eine Studie zur transnationalen Vermittlung von Care-Arbeit [Organizing Care Across Boundaries. A Study on Transnational Care Agencies]. Frankfurt am Main: Mabuse.

Lipszyc, B., Sail, E. \& Xavier, A. (2012). European Economy. Long-Term Care: Need, Use And Expenditure in the EU-27. Economic Papers 469. Brussels: Directorate-General for Economic and Financial Affairs.

Lutz, H. \& Palenga-Möllenbeck, E. (2010). Care work migration in Germany: Semi-compliance and complicity. Social Policy \& Society 9(3): 419-430.

Maarse, H. \& Jeurissen, P. (2016). The policy and politics of the 2015 longterm care reform in the Netherlands. Health Policy 120(3): 241-245.

MDS (Medizinischer Dienst des Spitzenverbandes der Krankenkassen). (2017). Qualität in der ambulanten und stationären Pflege [Quality in Inpatient and Outpatient Care]. Essen: Medizinischer Dienst des Spitzenverbandes Bund der Krankenkassen.

Monitor Langdurige Zorg (Long-term Care Monitor). (2018). Gebruik bijdrageplichtige Wlz-zorg [Use of Long-term Care]. Available on http:/ / mlzstatline.cbs.nl/Statweb/publication/?DM=SLNL\&PA=40055NED (Accessed: May 15, 2018).

Mosca, I., van der Wees, P. J., Mot, E. S., Wammes, J. J. G. \& Jeurissen, P. P. T. (2017). Sustainability of long-term care: Puzzling tasks ahead for policy-makers. International Journal of Health Policy and Management 6(4): 195-205.

Mot, E. (2010). The Dutch System of Long-Term Care. CPB Document 204. The Hague: CPB Netherlands Bureau for Economic Policy Analysis. 
Mot, E., Aouragh, A., De Groot, M. \& Mannaerts, H. (2010). The Long-Term Care System for the Elderly in the Netherlands. ENEPRI Research. Report No. 90. Brussels: Centre for European Policy Studies.

Neuhaus, A., Isfort, M. \& Weidner, F. (2009). Situation und Bedarfe von Familien mit mittel- und osteuropäischen Haushaltshilfen [Situation and Demand of Families with Care Workers from Central and Eastern Europe]. Köln: Deutsches Institut für angewandte Pflegeforschung e.V.

OECD (Organisation for Economic Cooperation and Development). (2017). Health at a Glance 2017: OECD Indicators. Paris: OECD Publishing.

Pfau-Effinger, B. (2005). Culture and welfare state policies: Reflections on a complex interrelation. Journal of Social Policy 34(1): 3-20.

Pinquart, M. (2016). Belastungs- und Entlastungsfaktoren pflegender Angehöriger - die Bedeutung der Erwerbstätigkeit [Burden and burden relief factors of family caregivers - the importance of employment]. In: Zentrum für Qualität in der Pflege (ed.), Vereinbarkeit von Beruf und Pflege (pp. 60-72). Berlin: Zentrum für Qualität in der Pflege.

Rossow, V. \& Leiber, S. (2017). Zwischen Vermarktlichung und Europäisierung: Die wachsende Bedeutung transnational agierender Vermittlungsagenturen in der häuslichen Pflege in Deutschland [Between marketization and europeanization: The Increasing significance of transnationally operating placement agencies in home care in Germany]. Sozialer Fortschritt 66: 285-302.

Sadiraj, K., Oudijk, D., van Kempen, H. \& Stevens, J. (2011). De opmars van het PGB. De ontwikkeling van het persoonsgebonden budget in nationaal en internationaal perspectief [The Rise of the PGB. The Development of the Personal Budget in National and International Perspective]. Den Haag: Sociaal en Cultureel PlanbureauSchwiter.

Scheiwe, K. (2010). Die soziale Absicherung häuslicher Pflege über Grenzen hinweg - Rechtliche Grauzonen, (Ir-)Regularität und Legitimität [Social protection of domestic care across borders - Legal grey zones, (ir-)regularity and legitimacy]. In K. Scheiwe \& J. Krawietz (eds.), Transnationale Sorgearbeit: Rechtliche Rahmenbedingungen und gesellschaftliche Praxis (pp. 123-150). Wiesbaden: VS Verlag für Sozialwissenschaften.

Schwiter, K., Berndt, C. \& Truong, J. (2018). Neoliberal austerity and the marketisation of elderly care. Social \& Cultural Geography 19(3): 379-399. 
International Journal of Ageing and Later Life

Sociale Verzekeringsbank (2016). Jaarcijfers [Annual Figures]. Available on https://www.svbkennisplatform.nl/jaarcijfers-2016/ (Accessed: May $8,2018)$.

Statista (2018). Kosten eines Pflegeheimplatzes in deutschland nach Pflegestufe im Jahr 2011 [Costs for a place in a residential care home by degree of dependency]. Available on https://de.statista.com/statistik/daten/ studie/196945/umfrage/kosten-eines-pflegeheimplatzes-in-deutschland/ (Accessed: February 10, 2018).

Statistisches Bundesamt (2017). Pflegestatistik 2015. Pflege im Rahmen der Pflegeversicherung. Deutschlandergebnisse [Statistics on LTC Recipients 2015]. Wiesbaden: Statistisches Bundesamt.

Stiftung Warentest (2017). Pflege zu Hause. Die besten Vermittler für Betreuungskräfte aus Osteuropa [Care at Home. The Best Placement Agencies for Care Workers from Eastern Europe]. Edition May 2017.

Tonkens, E. (2011). The embrace of responsibility: Citizenship and governance of social care in the Netherlands. In J. Newman \& E. Tonkens (eds.), Participation, Responsibility and Choice: Summoning the Active Citizen in Western European Welfare States (pp. 45-66). Amsterdam: Amsterdam University Press.

Van Bochove, M., zur Kleinsmeide, D. \& Ashu, S. (2017). Kwetsbaar en dan. Hoe inwonende buitenlandse zorgverleners en hun werkgevers omgaan met precaire arbeid [Vulnerable and Then. How Foreign Resident Carers and Their Employers Deal with Precarious Work]. Onderzoeksrapport. Rotterdam: Erasmus University Rotterdam.

Van den Broek, T. (2016). Supporting Ageing Parents: Comparative Analyses of Upward Generational Support. Rotterdam: Erasmus University Rotterdam.

Van Grafhorst, A. (2014). Verantwoorde buitenlandse zorg aan huis. Een verkennend onderzoek naar inwonende buitenlandse zorgverleners in Nederland [Responsible Care of Foreign Caregivers at Home. An Exploratory Study of Foreign Caregivers in the Netherlands]. Amsterdam: WEMOS.

Van Hooren, F. (2012). Varieties of migrant care work: Comparing patterns of migrant labour in social care. Journal of European Social Policy 22(2): 133-147.

Van Hooren, F. (2014). Migrant care work in Europe: Variety and institutional determinants. In M. Léon (ed.), The Transformation of Care in European Societies (pp. 62-82). London: Palgrave Macmillan. 
Van Hooren, F. \& Becker, U. (2012). One welfare state, two care regimes: Understanding developments in child and elderly care policies in the Netherlands. Social Policy \& Administration 46(1): 83-107.

Wetzstein, M., Rommel, A. \& Lange, C. (2015). Pflegende Angehörige Deutschlands größter Pflegedienst [Family Caregivers - Germany's Largest Care Service]. GBE kompakt 6(3). Berlin: Robert Koch-Institut.

Williams, F. (2012). Converging variations in migrant care work in Europe. Journal of European Social Policy 22(4): 363-376.

ZQP (Zentrum für Qualität in der Pflege). (2017). ZQP-Report Gewaltprävention in der Pflege [ZQP-Report Violence Prevention in Care]. Berlin: Zentrum für Qualität in der Pflege. 
